\title{
Entrepreneurial Self Efficacy Influence on the Creation of University Spin-off firms in Kenya
}

\author{
Wilberforce Senelwa ${ }^{1}$, Elegwa Mukulu ${ }^{2}$, John Kihoro ${ }^{3}$ \\ ${ }^{1,2}$ School of Entrepreneurship, Procurement and Management, Jomo Kenyatta University of Agriculture and \\ Technology (JKUAT), P.O Box 62000-00200, Nairobi, Kenya. \\ ${ }^{3}$ Directorate of Computing and E-Learning, Cooperative University of College of Kenya (CUCK), P.O Box \\ 24814-00502, Karen, Nairobi, Kenya.
}

\begin{abstract}
Entrepreneurship researchers have over the years pointed out the critical influence of self-efficacy on different aspects of a new venture creation process. In combination with environmental factors within and without university, entrepreneurial self-efficacy enables individuals to successfully perform the tasks and roles of an entrepreneur and hence meeting his/her expectations towards creating a new venture. This paper examines the influence of university context on the relationship between entrepreneurial self-efficacy and creation of university spin-off firms in Kenya. The sample comprised of 323 students and staff form top ten universities in Kenya. Results suggest that academics have a high intention to be entrepreneurs. Entrepreneurial self-efficacy ESE has a strong effect on creation of spin-off firms. The results of the study were compared with a previously published study conducted in the Turkey and Malaysia.
\end{abstract}

Keywords: Entrepreneurial Intention, Entrepreneurial Self-Efficacy,Spin-off firms.

\section{Introduction}

The spin-off firms in Kenya are a product of interaction between three main actors: university, industry and government. This is proposed in the Triple Helix model developed by (Etzkowitz \& Leydesdorff, 1997) . In the model, universities focus on establishing institutional interface structures including industry liaison/technology transfer offices, business and technology incubators, science and industrial parks and fostering entrepreneurialism through various policies and incentives (Etzkowitz, 2008; Kalar \& Antoncic, 2015).

In this regard, several public and private universities have since established industrial, science and technology parks promote the creation of spin-off firms. For instance, in 2007, MasindeMuliro University of Science and Technology (MMST) established the Directorate of Science \& Technology Park and Industrial Linkages (STPIL) under Planning, Research and Extension Division. The mandate was to start, develop and manage the university Science and Technology Park (STP) and market investment opportunities emanating from the research carried out within and outside the university. In January 2012, Egerton University started an AgroPark Project to act as a major player in provision of some practical solutions to the problems encountered in the implementation of projects under the Kenya Vision 2030. In February, 2012, Ministry of Industrialization and Jomo Kenyatta University of Agriculture and Technology (JKUAT) launched a 2.2 billion Industrial and Technology Park designed to contribute to Kenya's growth to a newly industrialized economy within the broad framework of Vision 2030 by providing avenue for university researchers to incubate and commercialize their innovations.

Therefore, it is evident from this background that over the last decades, an increasing interest has developed in the field of technology transfer from academic institutions, and as part of this a growing awareness of the importance of university spin-offs that academic entrepreneurship has evolved. The literature on academic entrepreneurship intention, commercialization of research based knowledge and university spin-offs is fairly rich, but the determinants of academic-entrepreneurial intention hugely lack empirical evidence (Prodan \& Drnovsek, 2010).

\subsection{StatementoftheProblem}

For a long time the universities in Kenya has been performing the four primary functions teaching promoting human resource development by producing high level human power in all fields of study; research and disseminating knowledge; fostering moral values and raising social consciousness and consultancy and service (Guerrero \& Urbano, 2012). But with the inauguration on Vision 2030 in 2007 and enactment of Science, Technology Innovation (STI) policy 2012, they role and once changed to be "entrepreneurial universities". Guerrero and Urbano (2012) observe that Universities may be considered entrepreneurial when they are not afraid to maximize the potential for commercialization of their ideas and create value in society without seeing this as a threat to academic values. Technology incubation and business matching initiatives have been implemented to commercialise local research and development output through setting up of start-up companies or technology licensing (Kilonzo \& Nyambegera, 2014) . To these end, private, public and higher 
learning institutions have started the business incubation initiatives.

In 2011, The University of Nairobi launched AfriLab centre with the aim of bringing together student innovators with the objective of designing new products. In April 2013, Strathmore University with support from idea Foundation, launched ilabAfrica innovation centre. The state-of-the-art facility accommodate up to 50 entrepreneurs who are not only given seed capital to kick-start their projects but are also given offices for Business Process Outsourcing (BPOs), business mentorship and consultation services. On the other hand, in May 2013, Kenyatta University, with the support from the Chandaria Foundation inaugurated Chandaria Business Innovation and Incubation Centre that costed over Sh50 million. The centre admits 18 to 25 students for entrepreneurship training for between six months and a year(ROK, 2012). Although, individual academic entrepreneurs are at the heart of academic entrepreneurship, universities should have incentive and reward systems for those academics at both individual and departmental levels that actively invigorate entrepreneurial behaviour and support spin-off firm creation(Krueger \& Carsrud, 1993).

Despite the decade long concerted efforts that have been done by the Government-Industry-University collaborations to create a culture of innovation on campuses and instill an entrepreneurial mindset in every graduate and faculty member,minimal tangible results have been exhibited in stimulating and entrenching innovation and value-addition activities in the marketplace that lead to successful spin-offs formation (ROK, 2012). Therefore, thepurpose of this study is to articulate some of the strength of an individual's beliefs that he/she is capable of successfully performing the roles and tasks of an entrepreneur and enterprise development.

\subsection{ResearchObjectives}

1. To establish how entrepreneurial self-efficacy influences the formation of university spin-off firms in Kenya.

2. To investigate how university context elements moderates the relationship between entrepreneurial selfefficacy academic entrepreneurial intentions and the creation of university spin-off firms in Kenya.

\subsection{Research Hypothesis}

$\mathrm{H}_{01}$ : Entrepreneurial self-efficacy has no significant influences on the formation of university spin-offfirms in Kenya.

$\mathrm{H}_{02}$ : University contexthas no significant moderating effect on the relationship between

Entrepreneurial self-efficacy and the creation of university spin-off firms in Kenya.

\section{Literature Review}

This study analyzed the influence of university context on the relationship between entrepreneurial selfefficacy andcreation of spin-off firms in Kenya.

\subsection{Theoretical Review}

\subsubsection{A stage model of academic spin-off creation}

Academic entrepreneurship is not a single event, but rather a continuous process comprised of a series of events (Friedman \& Silberman, 2003) hence the formation of university spin-offs was viewed under the stage model of academic spin-off creation.Ndonzuau, Pirnay and Surlrmont (2002) identify four stages as relevant in explaining the transformation of academic research results into economic value. Each of these four stages has a specific function in the global spin-off process. The first stage generates and assesses ideas with regard to possible commercialisation; the second stage considers these ideas and translates the most promising of them into genuine entrepreneurial projects; the third stage realizes the best projects by creating new spin-off firms; and the fourth stage consolidates and strengthens the economic value created by these new firms (Ndonzuau, Pirnay, \& Surlemont, 2002).

Ndonzuau et al., (2002) observed that the four stages are entirely dependent of each other. Economic value depends on the quality of firms, which depends on the quality of finalized projects, which themselves depend on the quality of the initial ideas. However, the third stage deals with the creation of a new firm to exploit an opportunity managed by a professional team and supported by available resources. These are the three key pillars of any entrepreneurial success (Timmons \& Spinelli, 1999). The issues that have to be dealt with will progressively move away from specific academic contingencies towards business considerations. In this regard, a stage model of academic spin-off creation clearly explains the current study by focusing on the global process of valorisation by spin-off from academic research institutions such as universities, laboratories, research centres.

Wood (2011) contends that there are two most commonly used formal mechanisms by which universities transfer intellectual property to outside parties is via use of technology licensing agreements or the launch of a completely new business, typically called a 'spin-off.' From this theoretical underpinning, creation of new firm invariably became the depend variable whose response not only concretely showed the transfer of research results to the market place but it response to academic entrepreneurial intentions was observed as the 
main objective of the study.

\subsubsection{Social Learning Theory}

The theory expounds human behavior as "a product of the interplay of intrapersonal influences, the behavior individuals engage in, and the environmental forces that impinge upon them"(Bandura, 1977). The interactions among these factors shape one's beliefs in having the ability to successfully perform a specific behavior in a certain situation and his/her expectations towards the outcomes of the behavior (Bandura, 1982). Boyd and Vozikis (1994) suggest that the concept of self-efficacy, derived from social learning theory plays an important role in the development of entrepreneurial intentions and actions. The self-efficacy perspective is highly appropriate for this study because entrepreneurial self-efficacy is about individuals' beliefs regarding their capabilities for attaining success and controlling cognitions for successfully tackling challenging goals during the entrepreneurial tasks. In other words, entrepreneurial self-efficacy refers to the strength of an academic's belief that he or she is capable of successfully performing the roles and tasks of an entrepreneur (Boyd \& Vozikis, 1994; Scherer, Adams, \& Wiebe, 1989)

\subsubsection{Social Network Theory}

Social network theory views social relationships in terms of nodes and ties. Nodes are the individual actors within the networks, and ties are the relationships between the actors. The importance of social ties to successful entrepreneurship is well established (Birley, 1986; Wood, 2011). Social network theory emphasizes that the attributes of individuals are less important than their relationships and ties with other actors within the network. Numerous review of literature divides the challenges facing the academic entrepreneur into two basic tasks: the identification of a promising opportunity and the mobilization of resources to exploit it. Tesfom (2006) posits that social networks influence both of these stages of the entrepreneurial process: they shape information flows and trace the ties through which financial capital flows.

Academic Entrepreneurs require information, capital, skills, and labor to start business activities. While they hold some of these resources themselves, they often complement their resources by accessing their contacts and social relations (Arnold, Timothy, \& Carolyn, 1995; Hansen, 1995; Tesfom, 2006). Therefore, Social networks theory enhances academic entrepreneurial intentions into three components: provide academic entrepreneurs with information (e.g., market information, new opportunities) as well as tangible resources (e.g., human resources, financial resources) as well as in- tangible resources (e.g., social support, problem solving) held by other actors (Hoang \& Antoncic, 2003; Nicolaou \& Birley, 2003; Shane \& Stuart, 2002; Walter, Auer, \& Ritter, 2006).

\subsection{Conceptual Framework}

A conceptual framework is a set of broad ideas and principles taken from relevant fields of enquiry and used to structure a subsequent presentation (Kombo \& Tromp, 2006). A conceptual framework explores the relationship between independent variables, moderating and dependent variables. The conceptual framework for this study show the relationship between entrepreneurial self-efficacy and the creation of university spin-off firms with university context being the moderating variable. The variables in the conceptual framework are originated from the theories and the models in the theoretical framework.

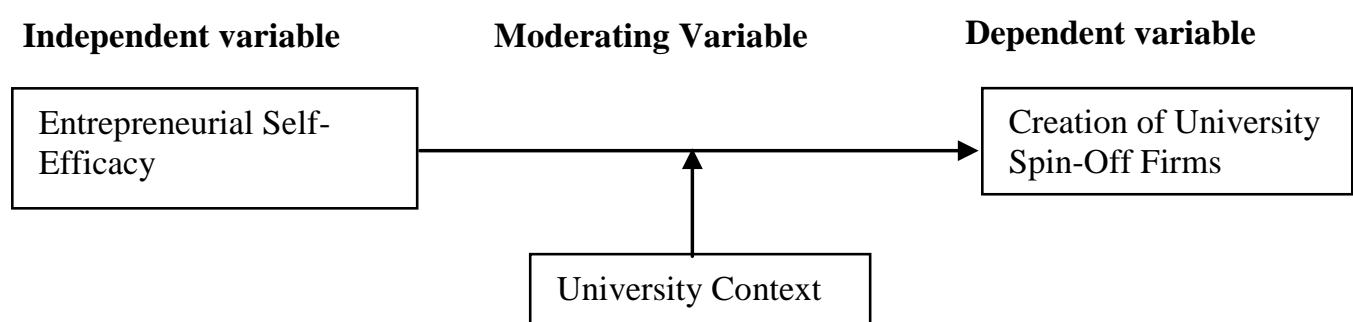

Figure 1: Conceptual Framework

\subsubsection{Creation of University Spin-off firms}

Creation of University was seen through 'a stage model of academic spin-off creation, (Ndonzuau et al., 2002) . Ndonzuau et al. (2002) build up a general model that puts forward the major issues involved in the transformation of research results into the creation of economic value within the perimeter of universities. Hence the model is composed of four successive stages interacting in a sequential manner i.e Stage 1: to generate business ideas from research; Stage 2: to finalize new venture projects out of ideas; Stage 3: to launch spin-off firms from projects; Stage 4: to strengthen the creation of economic value by spin-off firms. 


\subsubsection{Entrepreneurial Self-Efficacy}

The relationship between Entrepreneurial Self Efficacy (ESE) perception and entrepreneurial intention that leads to creation on new venture has been discussed in several studies (Chen, Greene, \& Crick, 1998; Jung, Ehrlich, De Noble, \& Baik, 2001; Kickul \& D'Intino, 2005) . Individuals and their behavioural processes are the first concepts that appear when entrepreneurship is discussed. For this reason, individuals with higher ESE belief are likely to be entrepreneurs. ESE belief can be defined as the perception of an individual about the capabilities of being an entrepreneur and the belief for performing entrepreneurship roles and tasks successfully (Boyd \& Vozikis, 1994; Chen et al., 1998; Forbes, 2005; Luthans \& Ibrayeva, 2006).

Launching a new venture is a social process, because the entrepreneur is at the interaction with other people in the society while gathering the required resources so as to find the opportunity. Also, the social environment, from the point of socio-psychological context, has important effect on the motivation, perception and attitude of the individual. Within this framework, ESE belief may be considered as an attitude towards launching a new venture in a specific social environment (Jung et al., 2001). High ESE is one of the prerequisites of potential entrepreneurs. Although high self-efficacy individuals evaluate the business environment as full of opportunities, low self-efficacy individuals perceive the same environment as full of obstacles.

\subsubsection{University Context}

Environmental conditions such as access to venture funding, governmental regulations, and closeness to markets is seen as attributes of the opportunity or business idea. For instance, commercializing a new invention might be easier in an environment (region) with many potential customers. Individuals in other environments may, however, not consider the same invention to be an entrepreneurial opportunity at all. Hence, the external environment affects which opportunities are created and pursued (Chrisman, Hynes, \& Fraser, 1995; Smilor, Gibson, \& Dietrich, 1990).

Smilor et. al (1990) found in their survey that the university played an important or very important role in 56\% of the spin-off company formations, a highly more significant role than any other organization. The most important role of the university was as a source of personnel. Academic entrepreneurship is found to be considerably higher in some research departments than other, even within the same field of science (Franklin, Wright, \& Lockett, 2001; Louis, Blumenthal, Gluck, \& Stoto, 1989) . Thus, the specific university context is probably playing an important role in the spin-off process. The formal university involvement in spin-offs can vary, and Steffensen et al., (2000) distinguishes between spontaneous and planned spin-offs, the latter including an organized effort from the parent organization Franklin et al., (2001) found that more successful universities in fostering spin-offs tended to be less skeptical of the role of surrogate entrepreneurs. Di Gregorio and Shane (2003) found evidence that a low inventor's share of royalties and a willingness to make equity investments in university start-up companies increase start-up activity. Hence, university policies seem to have an effect on the spin-off process.

The academic culture values publishing and disinterested research, while entrepreneurial activity may be a sensitive issue (Ndonzuau et al., 2002). Studies have found that the most significant barriers to the adoption of entrepreneurial friendly policies at universities are cultural and informational (Franklin et al., 2001). Chrisman et al. (1995) concluded that "supporting research and sending a message that faculty entrepreneurship will be valued is perhaps more important than the specific programs designed to foster economic development". Based on their study of professorial entrepreneurship, (Kenney \& Richard Goe, 2004) suggests that "being embedded in an academic department and disciplines with cultures that are supportive of entrepreneurial activity can help counteract the disincentives created by a university environment that is not strongly supportive of these activities." This indicates a complex structure where academics are part of different cultures in their discipline, department, university, and external environment.

\subsection{EmpiricalReview}

Discussions on influence of entrepreneurial self-efficacy on university creation of spin-off firms have been done by various authors. Creation of University was seen through 'a stage model of academic spin-off creation, ((Ndonzuau et al., 2002) . Ndonzuau et al. (2002) build up a general model that puts forward the major issues involved in the transformation of research results into the creation of economic value within the perimeter of universities. Hence the model is composed of four successive stages interacting in a sequential manner i.e Stage 1: to generate business ideas from research; Stage 2: to finalize new venture projects out of ideas; Stage 3: to launch spin-off firms from projects; Stage 4: to strengthen the creation of economic value by spin-off firms.

In a study titled 'Entrepreneurial self-efficacy and entrepreneurial intention: the Turkish case', Naktiyok, Karabey and Gulluce (2009) examine the relationship of entrepreneurial self-efficacy (ESE) and entrepreneurial intention in the Turkish culture. The scholars studied the sub-dimensions of ESE and the level 
of entrepreneurial intention was discussed (Naktiyok, Karabey, \& Gulluce, 2009). The sample comprised of 245 undergraduate students of a university in Turkey where the results suggested that students have a high intention to be entrepreneurs. ESE has a strong effect on entrepreneurial intention, but sub-dimensions of ESE have different impacts (Naktiyok et al., 2009). The scholars compared the results of the study compared with a previously published study conducted in the USA and Korea by a group of researchers. In this comparison, the national cultural context was considered as an influential factor in entrepreneurship

In a paper study titled 'Technology transfer and universities' spin-out strategies' by Lockett, Wright and Franklin (2003), focus is on the strategies that can be employed to promote the creation of spin-out companies and how they then manage the development of these companies. The scholars focus on the difference between those universities that have been most active in the area and those that have been least active. Using a survey of technology transfer/business development officers at 57 United Kingdom universities, the study indicated that the more successful universities have clearer strategies towards the spinning out of companies' and the use of surrogate entrepreneurs in this process. They observed that more successful universities were found to possess a greater expertise and networks that may be important in fostering spin-out companies.

According (Davidsson \& Wiklund, 2001) examines that the primary determinant of entrepreneurial intention is a person's conviction that starting and running one's own firm is a suitable alternative for him/her. This conviction is in its turn based on certain general attitudes that have psychological dispositions and domain attitudes that concern entrepreneurship. In the study, the researcher uses 300 Swedish each grouped in 6 different regions aged between 35-40 years old subjects.

The use a large sample from a relevant age cohort of the general population was to establish relatively weak influences with satisfactory statistical certainty.

Maina (2011) observes that most of the Kenyan college graduates find it demeaning and unattractive to engage in small and micro enterprises in the informal sector. Paradoxically, employment opportunities among Kenyan post-secondary school graduates remain low and for many of these graduates it is very difficult to find formal employment resulting in a negative return on investment in Kenyan education. One would expect that high unemployment - as is the case in Kenya - would drive many of these graduates to the informal sector where they could start small and micro-enterprises. This problem can be partially attributed to the curriculum orientation of most Kenyan colleges and universities that mainly biased towards preparing graduates for white color jobs. Kenyan college graduates are trained to be employment seekers instead of employment creators. Stimulating interest in entrepreneurship among college-going students, we believe, is one way the problem of youth unemployment in Kenya could be addressed. In spite of the paradox, entrepreneurship studies have paid little attention to entrepreneurial attitudes, beliefs and values of the youth in Kenya. Elsewhere studies have linked entrepreneurial intentions to venture creation (Carte et al, 2003; Kolvereid, 1996; Krueger et al., 2000).

\section{Research Methodology}

To investigate the influence of entrepreneurial self-efficacy on the creation of spin-offs in Kenya, a combination of exploratory, descriptive and causal method of researches was used. In the study, explanatory method provided the researcher with the flexibility to explore different aspects of entrepreneurial self-efficacy in relation to technology transfer. Descriptive research assisted in investigating specific areas of the study that needs response to who, what, when, where, why, and how of the research. Causal research helped to probe the correlation between the study variables. The estimated population for academic staff and students (both undergraduate and postgraduate) from Pure and Applied Sciences, Engineering, Technology, Business/Entrepreneurship faculties/ departments in the top ten universities in Kenya using the 2014 July Webometric Ranking of World universities was 152,064 by records of 2013/2014 academic year. Given the target population, the researcher used a formula to calculate the sample size to be 323 as proposed by Cooper and Schindler (2003). The researcher adopted simple random sampling technique to select the academics. This research employed both qualitative and quantitative methods in order to strengthen the validity of data and to uphold survey findings (Cooper \& Schindler, 2003). Questionnaires that had both open and close items were administered to both academic staff and students to collect data with a response rate of $92 \%$. Statistical package for Social Science (SPSS) version 21.0 for Windows 7 was used to analyze data. Whereas quantitative data was analyzed with inferential statistics, qualitative data was analyzed using categorization.

\section{Data Analysis and Results}

In evaluating the survey constructs, reliability test was doneto examine the degree to which individual items used in a construct are consistent with their measures(Nunnally, 1978). The study employed Cronbach's coefficient alpha to assess internal consistency; reliability of 0.70 is normally acceptable in basic research(Bryman \& Cramer, 1997). All the alpha coefficients ranged between 0.65 and 0.9 as shown in Table 1 
Table 1: Reliability coefficient of the study variables

\begin{tabular}{|l|l|l|l|}
\hline Variable & Number of items & Reliability Cronbach's Alpha & Comments \\
\hline Entrepreneurial self-efficacy & 12 & 0.68 & Accepted \\
\hline Creation of spin-offs & 9 & 0.77 & Accepted \\
\hline University Context & 11 & 0.69 & Accepted \\
\hline
\end{tabular}

Hypothesis One: Entrepreneurial self-efficacy has no significant influences on theformation of university spinoff firms in Kenya.

\section{Entrepreneurial self-efficacy and formation of university spin-off firms-Model Summary}

The coefficient of determination ( $\mathrm{R}$ squared) of 0.134 shows that $13.4 \%$ of formation of university spin-off firms can be explained by entrepreneurial self-efficacy. The adjusted R-square of $13.2 \%$ indicates that entrepreneurial self-efficacy in exclusion of the constant variable explained the change in formation of university spin-off firms by $13.2 \%$, the remaining percentage can be explained by other factors excluded from the model. $\mathrm{R}$ of 0.367 shows that there is positive correlation between creation of spin-off firms andentrepreneurial self-efficacy. The standard error of estimate $(0.45620)$ shows the average deviation of the independent variables from the line of best fit. These results are shown in Table 2.

Table 2: Entrepreneurial Self efficacy and Creation of Spin-off firms-Model Summary

\begin{tabular}{|l|l|l|l|l|}
\hline \multicolumn{4}{|l|}{ Model Summary } \\
\hline Model & $\mathrm{R}$ & $\mathrm{R}$ Square & Adjusted R Square & Std. Error of the Estimate \\
\hline 1 & $.367^{\mathrm{a}}$ & .134 & .132 & .45620 \\
\hline
\end{tabular}

\section{Entrepreneurial Self-efficacy andCreation of University Spin-off firms-ANOVA}

The result of Analysis of Variance (ANOVA) for regression coefficient as shown inTable 3 revealed $(\mathrm{F}=59.592$, $p$ value $=0.001)$. Since the $p$-value is less than 0.05 it means that there exists a significant relationship between entrepreneurial self-efficacy and creation of university spin-off firms in Kenya.

Table 3 Entrepreneurial Self-efficacy and Creation of University Spin-off firms-ANOVA ${ }^{\mathrm{b}}$

\begin{tabular}{|c|c|c|c|c|c|c|}
\hline \multicolumn{7}{|c|}{ ANOVA $^{b}$} \\
\hline \multicolumn{2}{|c|}{ Model } & Sum of Squares & $\mathrm{df}$ & Mean Square & $\mathrm{F}$ & Sig. \\
\hline \multirow[t]{3}{*}{1} & Regression & 12.402 & 1 & 12.402 & 59.592 & $.001^{\mathrm{a}}$ \\
\hline & Residual & 79.918 & 384 & .208 & & \\
\hline & Total & 92.320 & 385 & & & \\
\hline \multicolumn{6}{|c|}{ a. Predictors: (Constant), Entrepreneurial Self-Efficiency } & \\
\hline
\end{tabular}

\section{Entrepreneurial Self-efficacy and Creation of University Spin-off firms-Regression Weights}

The study hypothesized that entrepreneurial self-efficacy has no significant effect on creation of university spin-off firms in Kenya. The study findings indicated that there was a positive significant relationship between entrepreneurial self-efficacy and creation of university spin-off firms $(\beta=0.342$ and $p$ value $=0.004)$. Therefore, a unit increase in entrepreneurial self-efficacy index led to an increase in creation of university spinoff firms by 0.342 . Since the p-value was less than 0.05 as shown in Table 4 , the null hypothesis was rejected and the alternative hypothesis accepted. It can then be concluded that entrepreneurial self-efficacy influences creation of university spin-off firms Kenya.

Table 4 Entrepreneurial Self-efficacy and Creation of University Spin-off firms- Regression Weights

\begin{tabular}{|l|l|l|l|l|l|l|}
\hline \multicolumn{2}{|l|}{ Coefficients $^{\mathbf{a}}$ Model } & Unstandardized Coefficients & Standardized Coefficients & $\mathrm{t}$ & Sig. \\
\cline { 3 - 5 } \multicolumn{2}{|c|}{} & B & Std. Error & Beta & & \\
\hline \multirow{2}{*}{1} & $($ Constant $)$ & 2.172 & .167 & & 13.029 & .000 \\
\cline { 2 - 7 } & Entrepreneurial Self-Efficiency & .342 & .044 & .367 & 7.720 & .004 \\
\hline
\end{tabular}

\section{Discussion of findings on the relationship betweenentrepreneurial self-efficacy and creation of university Spin-off firms'}

The regression analysis on Table 4 revealed that entrepreneurial self-efficacy had aninfluence on creation of university Spin-off firmsin Kenya. For every unit increase inentrepreneurial self-efficacy, there was a corresponding increase by 0.342 in creation of spin-off firms. The Pearson product moment correlation coefficient revealed a moderate, positive and significant correlation between entrepreneurial self-efficacyand university Spin-off firms $(r=0.367, \mathrm{p}$-value $=0.004)$ significant at 0.05 level of significance. 
These results are consistent with previous studies investigating the entrepreneurial self-efficacy and creation of university Spin-off firms'. According to findings of a study conducted by Naktiyok et al., (2009) who surveyed 245 university students in Turkey; individuals who possess higher entrepreneurial self-efficacy belief are most likely to be entrepreneurs. Entrepreneurial self-efficacy belief is an explanatory variable that determines the power of the entrepreneurial intention and the possibility of this intention resulting in an entrepreneurial activity, so it differentiates entrepreneurs and others (Boyd \& Vozikis, 1994; Chen et al., 1998; Markman \& Baron, 2003). Most entrepreneurship literature affirms that high entrepreneurial self-efficacy is one of the prerequisites of potential entrepreneurs. Even though high self-efficacy individuals assess the business environment as full of opportunities, most often low self-efficacy individuals identify the same environment as full of obstacles.

Entrepreneurial self-efficacy belief raises the intention of creating a new venture according to the numerous researches. For instance, in a study on 140 undergraduate students, it was found that there was a positive and significant relationship between entrepreneurial self-efficacy perception including entrepreneurial skills such as marketing, innovation, management and financial control, risk taking, and entrepreneurial intention of launching a spin-off firm. The researchers posits that ones with higher self-efficacy evaluated the entrepreneurial opportunities better and could be able to see positive outcomes (Chen et al.1998). Similarly, it was stated that self-evaluation capability had direct effects on formimg a venture(Chandler \& Hanks, 1994). In a study performed on 272 students, it was indicated that there was a significant and positive relationship between entrepreneurial self-efficacy perception, including risk and uncertainty management, innovation and product improvement, interpersonal relations and network management, opportunity recognition, finding resources, developing and maintaining the innovative business environment and entrepreneurial(De Noble, Jung, \& Ehrlich, 1999).

Hypothesis Two: University context has no significant moderating effect onthe relationshipbetween Entrepreneurial Self-efficacy and creation of University Spin-off firms in Kenya.

\section{Regression Results for the moderating effect of University context on entrepreneurial self-efficacy and creation of University spin-off firms in Kenya}

To test the above hypothesis, moderated multiple regression was used to estimate the interaction effect and test the moderating effect of university context on the relationship betweenentrepreneurial self-efficacy and creation of University Spin-off firms. Table 5 shows the moderating effect of University context on Entrepreneurial Self-efficacy and creation of University Spin-off firms' model summary.

The coefficient of determination (R-Squared) of 0.131 shows that $13.1 \%$ of creation of University Spin-off firms can be explained by entrepreneurial self-efficacy. The adjusted R-square of $12.9 \%$ depicts that entrepreneurial self-efficacy in exclusion of the constant variable explained the change in the creation of University Spin-off firms by $12.9 \%$, the remaining percentage can be explained by other factors excluded from the model. An $\mathrm{R}=0.362$ means that there is a positive significant relationship between entrepreneurial selfefficacy and creation of university spin-off firms. The standard error of estimate $(0.45690)$ shows the average deviation of the independent variables from the line of best fit.

The second model shows the relationship between entrepreneurial self-efficacy, University context and creation of university spin-off firms. The change in R-square from $13.1 \%$ to $14.1 \%$ implies that University context enhanced the relationship between entrepreneurial self-efficacy and creation of university spin-off firms.

Table 5: Moderating effect of University context on entrepreneurial self-efficacy and creation of University Spin-off firms in Kenya-Model summary

\begin{tabular}{|c|c|c|c|c|c|c|c|c|c|}
\hline \multicolumn{10}{|c|}{ Model Summary } \\
\hline \multirow[t]{2}{*}{ Model } & \multirow[t]{2}{*}{$\mathrm{R}$} & \multirow[t]{2}{*}{ R Square } & \multirow{2}{*}{$\begin{array}{ll}\text { Adjusted } & \mathrm{R} \\
\text { Square } & \\
\end{array}$} & \multirow{2}{*}{$\begin{array}{l}\text { Std. Error of } \\
\text { the Estimate }\end{array}$} & \multicolumn{5}{|l|}{ Change Statistics } \\
\hline & & & & & R Square Change & F Change & df1 & df2 & Sig. F Change \\
\hline 1 & $.362^{\mathrm{a}}$ & .131 & .129 & .45690 & .131 & 57.218 & 1 & 380 & .000 \\
\hline 2 & $.375^{\mathrm{b}}$ & .141 & .136 & .45489 & .010 & 4.363 & 1 & 379 & .037 \\
\hline \multicolumn{10}{|c|}{ a. Predictors: (Constant), X1c } \\
\hline \multicolumn{4}{|c|}{ b. Predictors: (Constant), X1c, Z1c } & & & & & & \\
\hline
\end{tabular}

\section{Moderating effect of University context on entrepreneurial self-efficacy and creation of University Spin- off firms in Kenya -ANOVA}

The F-statistics was used to determine the validity of the model, in Table $6(\mathrm{~F}=57.218$, p-value $=0.001)$ shows that there is a significant relationship between creation of university spin-off firms and entrepreneurial self-efficacy and at least the slope ( $\beta$ coefficient) is not zero. Similarly, the F-statistics for the second model was $(\mathrm{F}=31.043$, $\mathrm{p}$-value $<0.001)$; therefore, it can be implied that there is a significant relationship between creation of university spin-off firmsand Entrepreneurial Self-efficacy and University context and at least one of the beta 
(slope) is not zero.

Table 6: Moderating Effect of University context on Entrepreneurial Self-efficacy and creation of University Spin-off firms in Kenya-ANOVA

\begin{tabular}{|c|c|c|c|c|c|c|}
\hline \multicolumn{7}{|c|}{ ANOVA $^{d}$} \\
\hline \multicolumn{2}{|c|}{ Model } & Sum of Squares & df & Mean Square & $\mathrm{F}$ & Sig. \\
\hline \multirow[t]{3}{*}{1} & Regression & 11.945 & 1 & 11.945 & 57.218 & $.001^{\mathrm{a}}$ \\
\hline & Residual & 79.327 & 380 & .209 & & \\
\hline & Total & 91.272 & 381 & & & \\
\hline \multirow[t]{3}{*}{2} & Regression & 12.847 & 2 & 6.424 & 31.043 & $.001^{\mathrm{b}}$ \\
\hline & Residual & 78.424 & 379 & .207 & & \\
\hline & Total & 91.272 & 381 & & & \\
\hline \multicolumn{7}{|c|}{ a. Predictors: (Constant), X1c } \\
\hline \multicolumn{4}{|c|}{ b. Predictors: (Constant), X1c, Z1c } & & & \\
\hline
\end{tabular}

\section{Moderating effect of University context on entrepreneurial self-efficacy and creation of University Spin- off firms in Kenya-Regression Weights}

The study findings showed that there was a positive significant relationship between entrepreneurial self-efficacy and creation of University Spin-off firms $(\beta=0.336$ and $p$-value=0.004) as shown in Table 7. Therefore, a unit increase in use of entrepreneurial self-efficacy ledto an increase in creation of University Spinoff firms by 0.336 . Since the p-value was less than 0.05 , the null hypothesis was rejected and concluded that entrepreneurial self-efficacy had a significant positive relationship with creation of university spin-off firms.

The second model depicted that there is a significant positive relationship between University context and creation of University Spin-off firms $(\beta=0.122$ and $p$-value $=0.004)$. Thus, it can be implied that a unit change in University context index increasescreation of University Spin-off firms' index by 1.22 units. A closer scrutiny of the entrepreneurial self-efficacy beta coefficient depicts that University context strengthens the positive relationship $(\beta=0.249$ and $p$-value < 0.001$)$ between entrepreneurial self-efficacy and creation of University Spin-off firms.

Table 7: Moderating effect of University context on entrepreneurial self-efficacy and creation of University Spin-off firms in Kenya-Regression Weights

\begin{tabular}{|c|l|l|l|l|l|l|}
\hline \multicolumn{2}{|l|}{ Model } & Unstandardized Coefficients & Standardized Coefficients & t & \multirow{2}{*}{ Sig. } \\
\cline { 3 - 5 } \multicolumn{2}{|l|}{} & B & Std. Error & Beta & & \\
\hline \multirow{2}{*}{1} & (Constant) & 3.447 & .023 & & 147.437 & .000 \\
\cline { 2 - 7 } & X1c & .336 & .044 & .362 & 7.564 & .004 \\
\hline \multirow{2}{*}{2} & (Constant) & 3.447 & .023 & & 148.093 & .000 \\
\cline { 2 - 7 } & X1c & .249 & .061 & .268 & 4.080 & .001 \\
\cline { 2 - 7 } & Z1c & .122 & .059 & .137 & 2.089 & .004 \\
\hline
\end{tabular}

Discussion of findings on the moderating effect of University contexton the relationship between entrepreneurial self-efficacy and creation of University Spin-off firms

The findings in Table 4 indicated that entrepreneurial self-efficacy positively andsignificantly influenced creation of University Spin-off firms $(\beta=0.342$, p-value 0.004$)$. For every unit increase in entrepreneurial self-efficacy, there was a corresponding increase in creation of University Spin-off firms by (0.342). The Pearson product moment correlation coefficient revealed a moderate, positive and significant correlation between creation of University Spin-off firms and entrepreneurial self-efficacy $(r=0.367$, $p$-value 0.004 ) significant at $5 \%$ level of significance.

The empirical findings of this study indicated that entrepreneurial self-efficacy influenced creation of University spin-off firms Kenya. These results are consistent with previous studies investigating theentrepreneurial self-efficacy influenced creation of University spin-off firms. The findings of the study support the work of Naktiyok et al., (2009) that provided empirical evidence for the hypothesized relationship between self-efficacy, self-regulation and behavior in educational settings and relating to Malaysian university students' entrepreneurial intentions. More specifically, the study confirmed that self-efficacy has the most significant positive effect on entrepreneurial career intentions among university students.

\section{Conclusion}

It can therefore be concluded from the findings of this study that entrepreneurial self-efficacy is the strongest determinant of university staff and students' intention of creating spin-off firms. Furthermore, university context also plays a key role in their decision to become an entrepreneur. This study contributes to empirical supports for the model of entrepreneurial self-efficacy, university context and creation of university spin-off firms. It is concluded that the model can be used by both educators' and entrepreneurship researchers in 
their attempts to improve entrepreneurial intention among academics.

\section{References}

[1] Arnold, C., Timothy, F., \& Carolyn, W. (1995). Entrepreneurial information search. Journal of Business Venturing, 10(2), 107-120.

[2] Bandura, A. (1977). Self-efficacy: toward a unifying theory of behavioral change. Psychological review, 84(2), 191.

[3] Bandura, A. (1982). Self-efficacy mechanism in human agency. American psychologist, 37(2), 122.

[4] Birley, S. (1986). Succession in the family firm: The inheritor's view. Journal of Small Business Management, 24(4), 36.

[5] Boyd, N. G., \& Vozikis, G. S. (1994). The influence of self-efficacy on the development of entrepreneurial intentions and actions. Entrepreneurship theory and practice, 18(3), 63-63.

[6] Bryman, A., \& Cramer, D. (1997). Quantitative data analysis with SPSS for Windows: Routledge London.

[7] Chandler, G. N., \& Hanks, S. H. (1994). Founder competence, the environment, and venture performance. Entrepreneurship: Theory and Practice, 18(3), 77-90.

[8] Chen, C. C., Greene, P. G., \& Crick, A. (1998). Does entrepreneurial self-efficacy distinguish entrepreneurs from managers? Journal of Business Venturing, 13(4), 295-316.

[9] Chrisman, J. J., Hynes, T., \& Fraser, S. (1995). Faculty entrepreneurship and economic development: The case of the University of Calgary. Journal of Business Venturing, 10(4), 267-281.

[10] Cooper, D. R., \& Schindler, P. S. (2003). Business research methods. Boston: McGraw Hill.

[11] Davidsson, P., \& Wiklund, J. (2001). Levels of analysis in entrepreneurship research: Current research practice and suggestions for the future. Entrepreneurship theory and practice, 25(4), 81-100.

[12] De Noble, A., Jung, D., \& Ehrlich, S. (1999). Initiating new ventures: The role of entrepreneurial self-efficacy. Paper presented at the Babson Research Conference, Babson College, Boston, MA.

[13] Etzkowitz. (2008). Triple helix innovation: Industry, university, and government in action. London and New York: Routledge.

[14] Etzkowitz, \& Leydesdorff, L. A. (1997). Universities and the global knowledge economy:A Triple Helix of University-IndustryGovernment Relations. London: Continuum.

[15] Forbes, D. P. (2005). The effects of strategic decision making on entrepreneurial self-efficacy. Entrepreneurship theory and practice, 29(5), 599-626.

[16] Franklin, S. J., Wright, M., \& Lockett, A. (2001). Academic and surrogate entrepreneurs in university spin-out companies. The Journal of Technology Transfer, 26(1-2), 127-141.

[17] Friedman, J., \& Silberman, J. (2003). University technology transfer: do incentives, management, and location matter? The Journal of Technology Transfer, 28(1), 17-30.

[18] Guerrero, M., \& Urbano, D. (2012). The development of an entrepreneurial university. The Journal of Technology Transfer, 37(1), 43-74.

[19] Hansen, E. L. (1995). Entrepreneurial networks and new organization growth. Entrepreneurship theory and practice, 19(2), 7-20.

[20] Hoang, H., \& Antoncic, B. (2003). Network-based research in entrepreneurship: A critical review. Journal of Business Venturing, 18(2), 165-187.

[21] Jung, D. I., Ehrlich, S. B., De Noble, A. F., \& Baik, K. B. (2001). Entrepreneurial self-efficacy and its relationship to entrepreneurial action: a comparative study between the US and Korea. Management International, 6(1), 41.

[22] Kalar, B., \& Antoncic, B. (2015). The entrepreneurial university, academic activities and technology and knowledge transfer in four European countries. Technovation, 36, 1-11.

[23] Kenney, M., \& Richard Goe, W. (2004). The role of social embeddedness in professorial entrepreneurship: a comparison of electrical engineering and computer science at UC Berkeley and Stanford. Research Policy, 33(5), 691-707.

[24] Kickul, J., \& D'Intino, R. S. (2005). Measure for measure: modeling entrepreneurial self-efficacy onto instrumental tasks within the new venture creation process. New England Journal of Entrepreneurship, 8(2), 6.

[25] Kilonzo, P. M., \& Nyambegera, S. M. (2014). Determinants of entrepreneurial intention among university business students in Kenya: lessons from Kenyatta University. International Journal of Entrepreneurship and Small Business, 22(2), 231-250.

[26] Kombo, D. K., \& Tromp, D. L. (2006). Proposal and thesis writing: An introduction. Nairobi: Paulines Publications Africa, 10-45.

[27] Krueger, N. F., \& Carsrud, A. L. (1993). Entrepreneurial intentions: applying the theory of planned behaviour. Entrepreneurship \& Regional Development, 5(4), 315-330.

[28] Louis, K. S., Blumenthal, D., Gluck, M. E., \& Stoto, M. A. (1989). Entrepreneurs in academe: An exploration of behaviors among life scientists. Administrative science quarterly, 110-131.

[29] Luthans, F., \& Ibrayeva, E. S. (2006). Entrepreneurial self-efficacy in Central Asian transition economies: quantitative and qualitative analyses. Journal of International Business Studies, 37(1), 92-110.

[30] Markman, G. D., \& Baron, R. A. (2003). Person-entrepreneurship fit: why some people are more successful as entrepreneurs than others. Human resource management review, 13(2), 281-301.

[31] Naktiyok, A., Karabey, C. N., \& Gulluce, A. C. (2009). Entrepreneurial self-efficacy and entrepreneurial intention: the Turkish case. International Entrepreneurship and Management Journal, 6(4), 419-435.

[32] Ndonzuau, F. d. r. N., Pirnay, F., \& Surlemont, B. (2002). A stage model of academic spin-off creation. Technovation, 22(5), 281289.

[33] Nicolaou, N., \& Birley, S. (2003). Academic networks in a trichotomous categorisation of university spinouts. Journal of Business Venturing, 18(3), 333-359.

[34] Nunnally, J. (1978). C.(1978). Psychometric theory: New York: McGraw-Hill.

[35] Prodan, I., \& Drnovsek, M. (2010). Conceptualizing academic-entrepreneurial intentions: An empirical test. Technovation, 30(5), 332-347.

[36] ROK. (2012). Sessional Paper No.1 of 2012 on policy framework for Science, Technology and Innovation Nairobi: Government Printer.

[37] Scherer, R. F., Adams, J. S., \& Wiebe, F. A. (1989). Developing entrepreneurial behaviours: A social learning theory perspective. Journal of Organizational Change Management, 2(3), 16-27.

[38] Shane, S., \& Stuart, T. (2002). Organizational endowments and the performance of university start-ups. Management science, 48(1), 154-170.

[39] Smilor, R. W., Gibson, D. V., \& Dietrich, G. B. (1990). University spin-out companies: technology start-ups from UT-Austin. Journal of Business Venturing, 5(1), 63-76.

[40] Tesfom, G. (2006). The role of social networks on the entrepreneurial drive of first generation East African origin entrepreneurs in the Seattle area. Journal of Asia Entrepreneurship and Sustainability, 2(3), 1-25. 
[41] Timmons, J. A., \& Spinelli, S. (1999). New venture creation: Entrepreneurship for the 21st century. Colombus: McGraw-Hill Higher Education.

[42] Walter, A., Auer, M., \& Ritter, T. (2006). The impact of network capabilities and entrepreneurial orientation on university spin-off performance. Journal of Business Venturing, 21(4), 541-567.

[43] Wood, M. S. (2011). A process model of academic entrepreneurship. Business Horizons, 54(2), 153-161. 